\title{
Comparison of the Efficiency and Side Effects of Syringe Size in Spinal Anesthesia
}

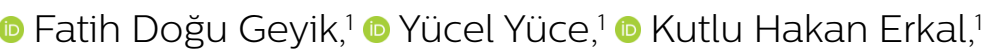 \\ (1) Banu Eler Çevik, 이 Necati Çıtak²
}

'Department of Anesthesiology and Reanimation, Health Sciences University Kartal Dr. Lütfi Kırdar Training and Research Hospital, İstanbul, Turkey

${ }^{2}$ Department of Thoracic Surgery Bakırköy Sadi Konuk Training and Research Hospital, İstanbul, Turkey

Submitted: 14.02.2018 Accepted: 06.08.2018

Correspondence: Fatih Doğu Geyik, SBÜ Kartal Dr. Lütfi Kırdar Eğitim ve Araştırma Hastanesi, Anesteziyoloji ve Reanimasyon Kliniği İstanbul, Turkey

E-mail: dogugeyik@hotmail.com

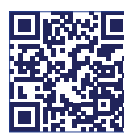

Keywords: Cesarean section; subarachnoid block; syringe diameter.

\begin{abstract}
Objective: Obstetric anesthesia and analgesia are administered to reduce pain during labor. The effect of 3 different-sized injectors $(2.5 \mathrm{~mL}, 5 \mathrm{~mL}, 10 \mathrm{~mL})$ used to achieve a subarachnoid block, each containing the same volume of local anesthesia, were analyzed, as well as complications and patient hemodynamics.
\end{abstract}

Methods: A total of 120 patients of American Society of Anesthesiologists classification I or II in the age group of 18 to 45 years who underwent a cesarean section with subarachnoid anesthesia were enrolled in the study. In Group I, 2.5-mL injectors were used; in Group II, 5-mL injectors were used; and 10-mL injectors were used in Group III. The hemodynamic parameters of all of the patients were recorded. Postoperative Bromage scale and pinprick tests were performed to assess motor and sensorial block levels, and time for recovery from the block was also recorded. Postoperative complications (headache, lumbar pain), and any requirement for an epidural blood patch was noted.

Results: There was a statistically significant difference in the time to reach T4 dermatome between Group I and Group II $(p=0.002)$. The time required was $2.5 \pm 0.8$ minutes for Group I, while it was $3.2 \pm 0.9$ minutes for Group II, and 3.2 21.0 minutes for Group III (Group I vs Group II: $p=0.00$ I, Group I vs Group III: $p=0.002$, Group II vs Group III: $p=0.843$ ).

Conclusion: The results indicated that the difference in the diameter of the injector had only a minimal effect on hemodynamic parameters. Further studies with other patient groups and different surgical procedures will produce more comprehensive results.

\section{INTRODUCTION}

Obstetric anesthesia and analgesia aim to reduce the pain during the labor. Anesthesia is needed for primarily ceaserian section (C-section), forceps induction, episiotomy, internal version, breech position, exclusion of the placenta, correction of the uterus inversion. ${ }^{[I]}$ The method of anethesia for C-section; based on to indication of the procedure, the emergence level of the operation, the request of the patient and the experience of anesthesiologist. There is no single ideal method for C-section. Both general and regional anaesthesia be used for elective cesarean section however, which of the two techniques is more ideal remains controversial.

Spinal anesthesia is the most common method of anesthesia for caesarean section. The anesthesiologist should prefer the method which is safe and comfortable for the mother, less depressant to the fetus and provide optimal conditions for the surgical operation. ${ }^{[2]}$ The regional anesthesia has some adventages. First of all no need for airway manipulation, protection of the airway reflexes, the de- crease of blood loss and depending on general anesthesia, the probability of fetal depression due to medications used and the continution of the analgesia during the postoperative period. ${ }^{[3,4]}$ Spinal anesthesia is defined will effect as the transient cessation of the nerve conduction by injection of a local anesthesic solution into the cerebrospinal fluid. [5] In pregnant patients, which there is an increase in intra abdominal pressure or dilatation of the epidural veins result with unwanted higher levels of block. This will cause respiratory depression in patients. ${ }^{[1,6]}$

There are several studies concerning the complications due to the needle diameter on spinal anaesthesia for Csection. According to our knowledge, but there are no studies evaluating the effects of different sized syringes on the duration of the blockage, the level of the dermatom and the complications during spinal anesthesia.

This study aimed to compare the haemodynamic effects of three different sized syringes $(2.5 \mathrm{~mL}, 5 \mathrm{~mL}, 10 \mathrm{~mL})$ with same volume of local anesthesics in partrituent patients undergoing $\mathrm{C}$-section. 


\section{MATERIAL AND METHODS}

This prospective, randomized, double blind study was conducted at the Obstetrics and Gynecology operation room of University of Health Sciences Kartal Dr. Lutfi Kirdar Training and Research Hospital. The study protocol conformed to the ethical guidelines of the Declaration of Helsinki. The study protocol was approved by ethics committee of University of Health Sciences Kartal Dr. Lutfi Kirdar Education and Research Hospital (Date: 30/0I/2018 Number: 2018/5I4/I22/I) and informed consent from the patients obtained separately before operation.

A total of I 20 patients had physical status I and II according to American Society of Anesthesiologists (ASA) aged 18 to 45 years scheduled for elective C-section under spinal anesthesia were enrolled in the study.

The inclusion criteria were as follow: candidates of elective cesarean section after 36 weeks of gestation, body mass index 18 to $35 \mathrm{~kg} / \mathrm{m}^{2}$, height more than $150 \mathrm{~cm}$, no history of addiction, no history of pre-eclampsia, eclampsia, or hypertension, and no contraindication for spinal anesthesia. The exclusion criteria included any contraindications for spinal anesthesia(infection on injection site, coagulation disorder, severe hypovolemia, increased intracranial pressure, aortic and/or mitral stenosis), patients with ASA physical status III or IV, preeclampsia, eclampsia, hypertension, diabetes mellitus, respiratory disorders, cardiac disorders, renal disorders, hepatic disorders, patients with coagulopathies, weight $>100 \mathrm{~kg}$, length $<150 \mathrm{~cm}$, age and fetal problems (bradycardia, polyhydramniosis) were excluded from the study. Patients with technical failure were excluded.

The patients were randomly divided into three groups of 40 each. In Group I; $2.5 \mathrm{~mL}$ syringe, in Group II; $5 \mathrm{~mL}$ syringe and in Group III; $10 \mathrm{~mL}$ syringe were used for subarachnoid anesthesia. The weight, height, ASA status and age of the patients were recorded. The level of spinal block, duration of sensory and motor block, and hemodynamic variables (mean blood pressure, systolic blood pressure diastolic blood pressure and heart rate), and complications were compared among the 3 groups.

Patients were admitted on the morning of surgery. Patients with 8-hour fast did not receive did not receive any pharmacological premedication. On arrival in the operating room, the patients were positioned on the operating table in the supine position with left uterine displacement, electrocardiogram, peripheral capillary oxygen saturation, and noninvasive blood pressure monitors (Mindray PM$8000 \mathrm{E}^{\circledR}$, Medical International Co., Ltd., China) were attached and baseline values of heart rate (HR) and blood pressure (BP) were noted. After inserted an 18-gauge intravenous cannula, all patients received an infusion of 10 $\mathrm{mL} . \mathrm{kg}^{-1}$ of Ringer's lactate administered in 10 min before spinal anesthesia. Using an aseptic technique, a 25-gauge Quincke spinal needle $\left(\right.$ Spinocan $^{\circledR}$, B. Braun Melsunger, Germany) was inserted intrathecally via median approach into the L4-5 interspaces, while the patient was in a sitting position. After confirmation of free flow of cerebrospinal fluid, $2.5 \mathrm{~mL}$ 0.5\% bupivacaine (AstraZeneca Company, France) was injected intrathecally, in all three groups. After confirming free flowing cerebrospinal fluid, In all 3 groups $2.2 \mathrm{~mL}$ of $0.5 \%$ (1 $2.5 \mathrm{mg}$ ) hyperbaric bupivacaine (AstraZeneca Company, France) injection was performed in 15-25 seconds with a $2 \mathrm{~mL}, 5 \mathrm{~mL}$ and $10 \mathrm{~mL}$ syringes. Injection was performed at a constant rate of $0.2 \mathrm{~mL} \cdot \mathrm{sec}^{-1}$. Immediately after spinal anesthesia, patients were placed in the supine position.

Then at I., 5., 10., 15., 20. and 30. minutes sensory and motor block were measured, systolic blood pressures (SBP), diastolic blood pressures (DBP), mean arterial pressures (MAP), heart rates and $\mathrm{SpO}_{2}$ values were recorded for $10 \mathrm{~min}$ and then every $5 \mathrm{~min}$ until the end of surgery. The sensory block was assessed using the pin prick method and motor block was assessed with modified Bromage score ( $\mathrm{l}=$ unable to move feet or knees, $2=$ able to move feet only, $3=$ just able to move knees, 4=full flexion of knees with detectable weakness of hip flexion while supine, $5=$ no detectable weakness of hip flexion while supine, 6=able to perform partial knee bend). After the sensory block achieved at the T4 dermatome the operation allowed. The time to reach maximum height of sensory block was also noted. All patients received supplemental oxygen ( 3 L. $\mathrm{min}^{-1}$ ) through an oxygen via a face mask until the umbilical cord was clamped.

Maternal side effects of spinal anesthesia like hypotension was considered when the mean arterial pressure decreased to more than $30 \%$ of baseline or less than 70 $\mathrm{mmHg}$. Hypotension was treated with incremental intra-

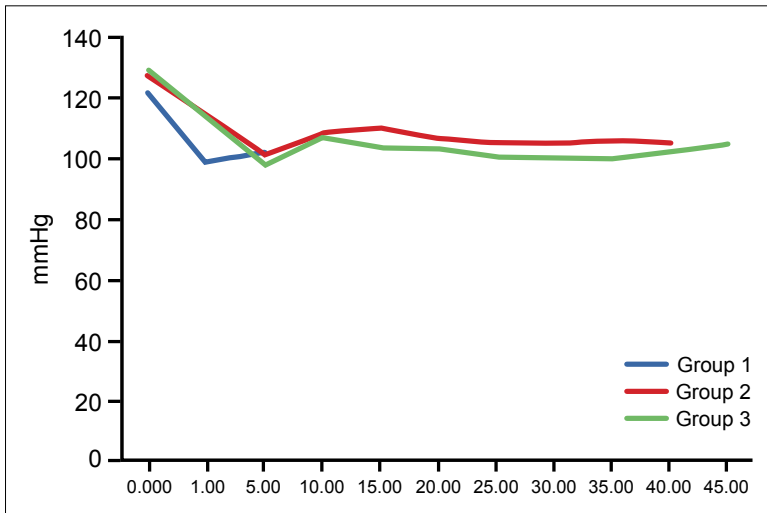

Figure 1. Changes in systolic blood pressures.

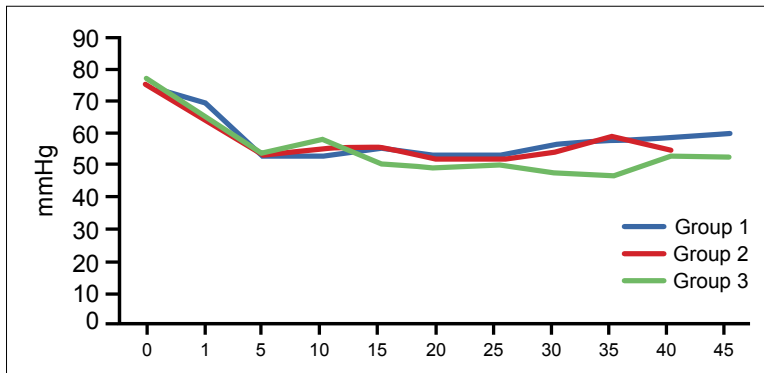

Figure 2. Changes in diastolic blood pressures. 


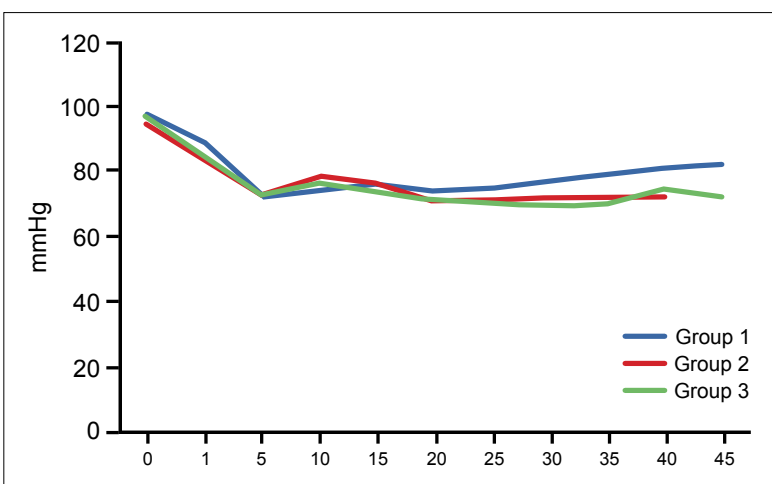

Figure 3. Change in maen arterial pressures.

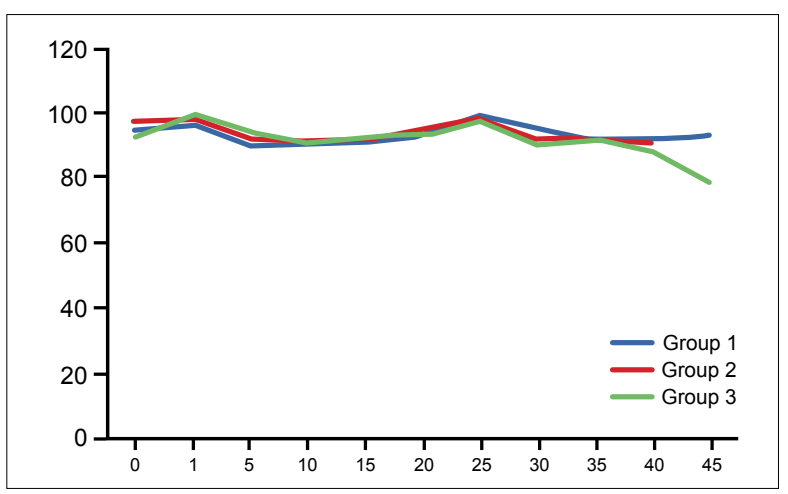

Figure 4. Change in heart rates.

venous doses of ephedrine. Similarly, bradycardia was defined as slowing heart rate of more than $30 \%$ of individual baseline or less than 60 beats per minute and treated up to $3 \mathrm{mg}$ intravenous atropine. Side effects such as nausea, vomiting, shortness of breath, were recorded and managed accordingly. Nausea and vomiting if any treated with injection ondansetron $4 \mathrm{mg}$ IV.

After the surgery, the patients were shifted to the postanesthesia care unit and standard monitoring was continued. The sensory level and motor blockade were assessed every 10 min. Postoperative modified Bromage scales and sensory Pinprick tests were performed for block levels and time for recovery of the blocks were recorded. The occurrence of postoperative headaches and lomber pain was also recorded.

\section{Statistical analysis}

The statistical analysis was performed with SPSS version 24.0 for Windows (SPSS, Chicago, IL). The distribution of the variables was evaluated by Kolmogorov-Smirnov test. For comparision of the groups according to the parametric data with normal distribution (mean \pm standart deviation), t-test was used. Mann-Whitney $U$ test was used for data with abnormal distribution (median \pm standart deviation). $\mathrm{P}<0,05$ was considered as statistically significant.

\section{RESULTS}

In all 3 groups, spinal block was successful and no high neuraxial block (level higher than T4) was recorded. As seen in Table I there was no significant difference in demographic characteristics of the patients and the ASA class of patients were comparable between the groups. The mean age of the patients was $26.7 \pm 6.3$ (I7-44) year, the mean weight was $73.3 \pm 11.5 \mathrm{~kg}$ and the mean length was $162.2 \pm 6.0 \mathrm{~cm}$.

The mean SBP was $129.4 \pm 13.7 \mathrm{mmHg}$, the mean DBP was $76.2 \pm \mathrm{Il} .3 \mathrm{mmHg}$ and the mean MAP was $96.4 \pm \mathrm{I} \mathrm{I} .9$ $\mathrm{mmHg}$. There were no significant differences between two groups in SBP, DBP and MAP ( $=0.278)$ (Table I).

There was no statatistically significant difference between the Group I and Group II in SBP (Fig. I, Table 2). There was statatistically significant difference between the Group II and Group III in SBP at I5th min values, between the Group I and Group III in SBP at Ist min ( $p=0.07)$, SBP at 25 th $\min (p=0.02)$, SBP at 30th $\min (p=0.007)$, SBP at 35 th $\min (p=0.008)$ and SBP at 40th $\min (p=0.08)$ values were statistically significant.

There was statistically significant difference between the Group I and Group II in DBP at Ist min ( $=0.07)$, there was no difference at other measurment times. There was statistically significant difference between the Group II and Group III in DBP at 35th $\min (p=0.03)$, there was no difference at measurment times (Fig. 2). There was statatistically significant difference between the Group I and Group III in DBP at Ist $\min (p=0.08)$, DBP at 10th $\min (p=0.06), D B P$ at I5th $\min (p=0.05), D B P$ at 20th $\min (p=0.04)$, DBP at 30th $\min (p=0.01)$, DBP at 35th min $(p=0.00 I)$ and DBP at 40th $\min (p=0.09)($ Table 3$)$.

Table I. The demographic characteristics and mean preoperative hemodynamic parameters

\begin{tabular}{|c|c|c|c|c|c|}
\hline & Mean \pm SD & Mean \pm SD & Mean \pm SD & Mean \pm SD & $\mathbf{p}$ \\
\hline Age (years) & $27.5 \pm 6.3$ & $24.8 \pm 6.4$ & $27.9 \pm 5.9$ & $26.7 \pm 6.3$ & 0.110 \\
\hline Length $(\mathrm{cm})$ & $161.4 \pm 6.4$ & $162.5 \pm 5.9$ & $162.7 \pm 5.8$ & $162.2 \pm 6.0$ & 0.342 \\
\hline Weight (kg) & $75.6 \pm 11.3$ & $70.9 \pm 11.4$ & $73.6 \pm 11.5$ & $73.3 \pm 11.5$ & 0.456 \\
\hline g-Systolic blood pressures (mmHg) & $131.6 \pm 13.5$ & $127.6 \pm 14.7$ & $129.1 \pm 13.0$ & $129.4 \pm 13.7$ & 0.507 \\
\hline $\mathrm{g}$-Diastolic blood pressures $(\mathrm{mmHg})$ & $75.8 \pm 9.5$ & $75.6 \pm 12.9$ & $77.1 \pm 11.3$ & $76.2 \pm 11.3$ & 0.680 \\
\hline $\mathrm{g}$-Mean arterial pressures $(\mathrm{mmHg})$ & $97.9 \pm 10.4$ & $94.3 \pm 13.4$ & $97.0 \pm 11.8$ & $96.4 \pm 11.9$ & 0.633 \\
\hline g-Heart rate $(n)$ & $94.0 \pm 12.5$ & $97.2 \pm 14.3$ & $93.2 \pm 16.3$ & $94.8 \pm 14.5$ & 0.434 \\
\hline g-S02 (\%) & $96.8 \pm 1.0$ & $97.4 \pm 0.9$ & $97.2 \pm 1.0$ & $97.1 \pm 1.0$ & 0.278 \\
\hline
\end{tabular}


Table 2. The changes in SBPs during the procedure and comparison between the groups

\begin{tabular}{|c|c|c|c|c|c|c|}
\hline & \multicolumn{3}{|c|}{ Groups } & \multicolumn{3}{|c|}{ p-values } \\
\hline & Group I $(n=39)$ & Group $2(n=40)$ & Group $3(n=4 I)$ & Group I vs 2 & Group I vs 3 & Group 2 vs 3 \\
\hline SBP-I & $|2| \pm 14.8$ & $115.7 \pm 18.5$ & $\mid 15.0 \pm 14.5$ & 0.162 & 0.07 & 0.850 \\
\hline SBP-5 & $99.9 \pm 23.1$ & $101.4 \pm 22.4$ & $98.8 \pm 19.3$ & 0.771 & 0.819 & 0.579 \\
\hline SBP- 10 & $102.7 \pm 15.9$ & $108.2 \pm 18.2$ & $107.0 \pm 16.1$ & 0.160 & 0.229 & 0.769 \\
\hline SBP-I5 & $107.8 \pm 14.7$ & $110.1 \pm 15.2$ & $104.0 \pm 12.6$ & 0.507 & 0.223 & 0.05 \\
\hline SBP-20 & $106.1 \pm 17.5$ & $107.0 \pm 11.9$ & $103.7 \pm 12.1$ & 0.793 & 0.464 & 0.212 \\
\hline SBP-25 & $108.1 \pm 14.0$ & $105.8 \pm 10.4$ & $101.6 \pm 10.3$ & 0.435 & 0.02 & 0.103 \\
\hline SBP-30 & $110.7 \pm 14.2$ & $105.8 \pm 9.7$ & $100.7 \pm 12.5$ & 0.169 & 0.007 & 0.139 \\
\hline SBP-35 & $111.5 \pm 12.8$ & $106.8 \pm 7.4$ & $100.6 \pm 11.7$ & 0.392 & 0.008 & 0.247 \\
\hline SBP-40 & $111.6 \pm 14.6$ & $105.0 \pm 6.0$ & $102.1 \pm 9.9$ & 0.452 & 0.08 & 0.650 \\
\hline SBP-45 & $112.8 \pm 12.2$ & - & $105.0 \pm 5.8$ & NA & 0.260 & NA \\
\hline SBP-50 & $114.3 \pm 11.5$ & - & $114.0 \pm 0.0$ & NA & 0.982 & NA \\
\hline SBP-55 & $125.0 \pm 7.0$ & - & $90.0 \pm 0.0$ & NA & 0.154 & NA \\
\hline SBP-60 & $140.0 \pm 0.0$ & - & $113.0 \pm 0.0$ & NA & NA & NA \\
\hline
\end{tabular}

SBP: Systolic blood pressures

Table 3. The changes in DBPs during the procedure and comparison between the groups

\begin{tabular}{|c|c|c|c|c|c|c|}
\hline & \multicolumn{3}{|c|}{ Groups } & \multicolumn{3}{|c|}{ p-values } \\
\hline & Group I $(n=39)$ & Group $2(n=40)$ & Grup $3(n=4 I)$ & Group I $(n=39)$ & Group $2(n=40)$ & Group 2 vs 3 \\
\hline DBP-I & $69.5 \pm 10.3$ & $64.4 \pm 13.9$ & $65.2 \pm 11.4$ & 0.07 & 0.08 & 0.787 \\
\hline DBP-5 & $53.3 \pm 13.0$ & $54.7 \pm 15.7$ & $54.2 \pm 13.0$ & 0.660 & 0.744 & $0.88 I$ \\
\hline DBP-I0 & $53.8 \pm 10.2$ & $55.8 \pm 12.7$ & $58.2 \pm 10.4$ & 0.444 & 0.06 & 0.356 \\
\hline DBP-I5 & $55.7 \pm 8.9$ & $55.7 \pm 13.7$ & $51.6 \pm 9.5$ & 0.990 & 0.05 & 0.119 \\
\hline DBP-20 & $53.7 \pm 10.2$ & $52.1 \pm 11.5$ & $49.4 \pm 8.6$ & 0.504 & 0.04 & 0.239 \\
\hline DBP-25 & $53.7 \pm 9.6$ & $52.2 \pm 11.9$ & $50.2 \pm 9.9$ & 0.558 & 0.130 & 0.462 \\
\hline DBP-30 & $56.2 \pm 10.0$ & $54.6 \pm 12.5$ & $48.9 \pm 10.8$ & 0.598 & 0.01 & 0.114 \\
\hline DBP-35 & $58.3 \pm 8.8$ & $59.5 \pm 13.7$ & $47.8 \pm 9.2$ & 0.790 & 0.001 & 0.03 \\
\hline DBP-40 & $59.4 \pm 10.0$ & $55.0 \pm 5.1$ & $53.1 \pm 6.0$ & 0.472 & 0.09 & 0.639 \\
\hline DBP-45 & $60.3 \pm 13.1$ & - & $52.3 \pm 7.2$ & NA & 0.351 & NA \\
\hline DBP-50 & $56.6 \pm 4.1$ & - & $63.0 \pm 0.0$ & NA & 0.318 & NA \\
\hline DBP-55 & $76.0 \pm 5.6$ & - & $43.0 \pm 0.0$ & NA & 0.132 & NA \\
\hline DBP-60 & $90.0 \pm 0.0$ & - & $46.0 \pm 0.0$ & NA & NA & NA \\
\hline
\end{tabular}

DBP: Diastolic blood pressures

There was statatistically significant difference between the Group I and Group II in MAP at Ist min and 30th min $(p=0.02$ and $p=0.07$, respectively). There was no statatistically significant difference between the Group II and Group III in MAP. There was statatistically significant difference between the Group I and Group III in MAP at Ist $\min (p=0.05)$, MAP at 15 th $\min (p=0.09)$, MAP at 25th min. $(p=0.05)$, MAP at 30th $\min (p=0.009)$ and MAP at 35th $\min (p=0.007)$ (Fig. 3, Table 4).

There was no statistically significant difference between the groups heart rates and $\mathrm{SpO}_{2}$ levels $(\mathrm{p}>0.05)$ (Table 5).

The ephedrine requirement was $69 \%(n=27)$ in Group I, $60 \%(n=24)$ in Group II and 58.5\% $(n=24)$ in Group III (Fig. 4). There was no statistically significant difference between the groups in ephedrine requirement ( $>>0.05)$ (Table 6).
There was statatistically significant difference between the Group I and Group II about the block time to reach T4 dermatome $(p=0.002)$. It was $2.5 \pm 0.8 \mathrm{~min}$ for Group I, $3.2 \pm 0.9 \mathrm{~min}$ for Group II and 3.2 $\pm 1.0 \mathrm{~min}$ for Group III (Group I vs Group II $p=0.00$ I, Group I vs Group III $p=0.002$, Group II vs Group III $p=0.843$ ).

There was no statatistically significant difference between the groups about the maximum dermatome level $(p=0.894)$ (Table 6).

\section{DISCUSSION}

In modern obstretrical anethesia procedures, regional anesthesia in elective $\mathrm{C}$-sections may be performed via spinal, epidural and combined spinal-epidural techniques. ${ }^{[7]}$ 
Table 4. The changes in MAPs during the procedure and comparison between the groups

\begin{tabular}{|c|c|c|c|c|c|c|}
\hline & \multicolumn{3}{|c|}{ Groups } & \multicolumn{3}{|c|}{ p-values } \\
\hline & Group I $(n=39)$ & Group $2(n=40)$ & Grup $3(n=4 I)$ & Group I $(n=39)$ & Group $2(n=40)$ & Group 2 vs 3 \\
\hline MAP-I & $89.7 \pm 12.2$ & $83.0 \pm 14.4$ & $84.6 \pm 11.2$ & 0.02 & 0.05 & 0.582 \\
\hline MAP-5 & $72.2 \pm 16.2$ & $73.0 \pm 17.5$ & $72.1 \pm 14.7$ & 0.836 & 0.969 & 0.797 \\
\hline MAP-IO & $74.4 \pm 11.6$ & $78.5 \pm 14.5$ & $76.5 \pm 13.5$ & 0.169 & 0.466 & 0.515 \\
\hline MAP-I5 & $76.6 \pm 9.3$ & $76.7 \pm 13.4$ & $73.0 \pm 9.7$ & 0.967 & 0.09 & 0.155 \\
\hline MAP-20 & $74.6 \pm 11.5$ & $71.9 \pm 10.7$ & $7 I .1 \pm 9.6$ & 0.282 & 0.142 & 0.724 \\
\hline MAP-25 & $75.2 \pm 10.7$ & $71.6 \pm 9.7$ & $70.4 \pm 10.5$ & 0.146 & 0.05 & 0.636 \\
\hline MAP-30 & $77.2 \pm 10.6$ & $72.2 \pm 9.2$ & $69.8 \pm 10.1$ & 0.07 & 0.009 & 0.420 \\
\hline MAP-35 & $79.0 \pm 9.8$ & $72.3 \pm 7.4$ & $70.6 \pm 8.8$ & 0.125 & 0.007 & 0.680 \\
\hline MAP-40 & $81.1 \pm 12.9$ & $72.3 \pm 5.0$ & $74.6 \pm 9.7$ & 0.266 & 0.197 & 0.706 \\
\hline MAP-45 & $82.3 \pm 13.3$ & - & $72.5 \pm 5.9$ & NA & 0.761 & NA \\
\hline MAP-50 & $74.3 \pm 11.5$ & - & $79.0 \pm 0.0$ & NA & 0.242 & NA \\
\hline MAP-55 & $101.0 \pm 12.7$ & - & $62.0 \pm 0.0$ & NA & NA & NA \\
\hline MAP-60 & $110.0 \pm 0.0$ & - & $74.0 \pm 0.0$ & NA & NA & NA \\
\hline
\end{tabular}

MAP: Mean arterial pressures

Table 5. The changes in hear rates during the procedure and comparison between the groups

\begin{tabular}{|c|c|c|c|c|c|c|}
\hline & \multicolumn{3}{|c|}{ Groups } & \multicolumn{3}{|c|}{ p-values } \\
\hline & Group I $(n=39)$ & Group $2(n=40)$ & Grup $3(n=4 I)$ & Group I $(n=39)$ & Group $2(n=40)$ & Group 2 vs 3 \\
\hline HR-I & $96.4 \pm 15.5$ & $98.0 \pm 19.9$ & $99.2 \pm 16.1$ & 0.686 & 0.427 & 0.768 \\
\hline HR-5 & $90.4 \pm 22.2$ & $92.1 \pm 15.5$ & $94.6 \pm 21.0$ & 0.687 & 0.388 & 0.552 \\
\hline HR-IO & $91.6 \pm 16.7$ & $91.7 \pm 19.2$ & $91.9 \pm 18.0$ & 0.909 & 0.937 & 0.852 \\
\hline HR-I5 & $91.7 \pm 17.3$ & $92.2 \pm 17.5$ & $93.5 \pm 13.9$ & 0.898 & 0.612 & 0.716 \\
\hline HR-20 & $93.2 \pm 17.5$ & $95.7 \pm 15.9$ & $93.6 \pm 14.2$ & 0.501 & 0.905 & 0.530 \\
\hline HR-25 & $99.0 \pm 16.7$ & $98.0 \pm 13.3$ & $97.2 \pm 14.0$ & 0.789 & 0.622 & 0.812 \\
\hline HR-30 & $95.0 \pm 14.8$ & $92.9 \pm 13.1$ & $90.7 \pm 13.2$ & 0.593 & 0.255 & 0.579 \\
\hline HR-35 & $92.1 \pm 12.2$ & $92.0 \pm 13.0$ & $92.1 \pm 15.4$ & 0.985 & 0.985 & 0.979 \\
\hline HR-40 & $91.3 \pm 15.2$ & $91.3 \pm 17.9$ & $88.2 \pm 14.7$ & 0.999 & 0.618 & 0.769 \\
\hline HR-45 & $93.3 \pm 19.1$ & - & $79.2 \pm 8.9$ & NA & 0.209 & NA \\
\hline HR-50 & $87.3 \pm 21.2$ & - & $100.0 \pm 0.0$ & NA & 0.657 & NA \\
\hline HR-55 & $98.5 \pm 17.6$ & - & $102.0 \pm 0.0$ & NA & 0.898 & NA \\
\hline HR-60 & $85.0 \pm 0.0$ & - & $119.0 \pm 0.0$ & NA & NA & NA \\
\hline
\end{tabular}

HR: Heart rate

Table 6. Comparison between the groups about ephedrine demand, ephedrine dose, time to arrive T6 level and maximum dermatome level

\begin{tabular}{|c|c|c|c|c|c|c|}
\hline & \multicolumn{3}{|c|}{ Groups } & \multicolumn{3}{|c|}{ p-values } \\
\hline & Group I $(n=39)$ & Group $2(n=40)$ & Grup $3(n=4 I)$ & Group I $(n=39)$ & Group $2(n=40)$ & Group 2 vs 3 \\
\hline \multicolumn{7}{|l|}{ Ephedrine demand } \\
\hline+ & $27 / 69.2 \%$ & $24 / 60.0 \%$ & $24 / 58.5 \%$ & 0.398 & 0.326 & 0.895 \\
\hline- & $12 / 30.8 \%$ & $16 / 40.0 \%$ & $17 / 41.5 \%$ & & & \\
\hline Ephedrine dose & $15.1 \pm 9.7$ & $12.7 \pm 8.3$ & $12.0 \pm 6.5$ & 0.338 & 0.195 & 0.774 \\
\hline Time to arrive T6 level & $2.55 \pm 0.81$ & $3.20 \pm 0.91$ & $3.24 \pm 1.06$ & 0.001 & 0.002 & 0.843 \\
\hline Maximum dermatomelevel & $4.79 \pm 0.92$ & $5.10 \pm 1.05$ & $4.82 \pm 0.99$ & 0.176 & 0.873 & 0.239 \\
\hline
\end{tabular}

HR: Heart rate

In regional anesthesia, the main aim is obtaining the loss of nerve conduction and sense of pain in a definite area of the body without loss of consciousness. It has some definite advantages like no loss of consciousness of the mother, no need for airway manipulation, protection of the airway reflexes, low risk of maternal pulmonary aspiration risk, 
less blood loss, low risk of fetal depression and contiuned analgesia at the postoperative period. ${ }^{[7-10]}$ But there are some potential complications like inadequate block, high level block, toxicity of local anesthesics and rarely neurological sequela, headache, lomber pain and hypotension. ${ }^{[8]}$ Commonly, spinal, epidural and combined spinal-epidural are used. ${ }^{[10]}$ There is a difference in the sensorial blocks in vaginal labors and $\mathrm{C}$-secions. In $\mathrm{C}$-sections sensorial blocks at T4 level is adequate but in vaginal labors it is TIO level. ${ }^{[7-10]}$

We investigated the effects of using different sized injectors during injection of the local anesthesics in spinal anesthesia. There are several studies in literature about certain characteristics of spinal needles and spinal anesthesia, but there is no similiar study concerning the effects of the pressure of syringes with different sizes.

The most common factor affecting the neural block level after spinal anesthesia are the baricity of the anesthesic solution, the position of the patient during and after the injection, drug dose and site of injection but the length of the patient, the anatomy of the vertebral column, age, drug volume, intraabdominal pressure and the direction of the needle are other factors. ${ }^{[8]}$

Hypotension within 10 minutes after the induction of anesthesia is the most common complication of the spinal anesthesia. Sympathic blockage with sensorial block is observed after induction of local anesthesics. The increase in venous ponding due to sympathic blockage and the decrease in systemic vascular resistance result with hypotension. Maternal dehydration, the decrease of venous return due to compression of the uterus to the inferior vena cava during supine position, the vagal activation due to retraction of the uterus and the peritoneum may cause deeper hypotension. Uterine blood flow depends on the perfussion pressure and hypotension causes the decrease in uterin blood flow and this result with distruption in fetal oxygenation. In addition, it may causes unpleasant symptoms such as nausea, vomiting, loss of consciousness, respiratory depression, and even shock. To prevent hypotension in regional anesthesia, fluid replacement before the procedure and prevention of the aortocaval pressure are the certain measures. $25 \%$ or more fall in maternal blood pressure when compared with preoperative levels or SBP $<90 \mathrm{mmHg}$ was accepted hypotension in obtetric patients. ${ }^{\left[{ }^{\prime I}\right]}$ Rapid fluid replacement, left lateral positioning of the patient should be performed in the treatment of the hypotension. If there is no increase in systolic pressure within few minutes, 5-10 $\mathrm{mg}$. IV bolus ephedrine should be given. Same doses may be repeated if there is no response. ${ }^{[I I]}$

In our study the statistically significant difference in SBP in Group I and III especially in I. minute was due to the increase in the diameter of the piston of the syringe. Similarly, the significant decrease in DBP and MAP in Group III was correlated with this result.

We found no significant difference in weight, length and ages. This may be due to the limited interval of the lengths of the patients. Harten et al. ${ }^{[12]}$ found the lesser incidence of hypotension, decrease in epehdrine demand and a decrease high spinal block levels when adjusted doses of local ansthesics due to the lengths and weights of the patients rather than a constant dose. Excessive dose adjustment, no decrease of the doses in special patient groups (e.g. elder, pregnant, obese, short) or pregnant patients are also more sensitive to to local anesthesics may cause this result.

We think that the indifference of the ephedrine demand and the heart rates between the groups are due to the similar patient demographics and the usage of same drug with same dose. This result made us to think that only the change in syringe made no statistically significant difference.

There was no statistically significant difference between 3 groups about the maximum dermatom level. This result is compatible with the same patient demographics and the same adjusted local anesthesic drug volume. But when the time period to achieve to T4 dermatome was examined, this time period was short in patients in Group I when compared with the ones in Group II and III. We think that this was due to the smaller diameter of the syringe while other parameters were same. In a study with urologic patients, there was no difference in motor and sensory blocks with 2 different injection times. ${ }^{[13]}$ This result suggests our results, but based on our findings we postulate that the rapid onset of motor and sensory blocks with small syringes although injection times and volumes are same is due to the decrease in diameter.

\section{CONCLUSION}

The usage of regional anesthesia in all age group and ASA classification of patients becomes more common with developing surgical techniques and decreasing durations of the operations. Although the factors affecting motor block and dermatome levels were known, We conclude that the change in the diameter of the syringe will produce a minimal effect. Further studies with other patient groups with different surgical procedures will produce more comprehensive results.

Ethics Committee Approval

Approved by the local ethics committee.

Informed Consent

\section{Retrospective study.}

Peer-review

Internally peer-reviewed.

Authorship Contributions

Concept: F.D.G., Y.Y.; Design: F.D.G., K.H.E.; Data collection \&/or processing: F.D.G., B.E.Ç.; Analysis and/or interpretation: F.D.G., N.Ç.; Literature search: F.D.G., K.H.E. Writing: F.D.G., Y.Y.; Critical review: F.D.G., B.E.Ç.

Conflict of Interest

None declared. 


\section{REFERENCES}

1. Kayhan Z. Klinik anestezi. 3rd ed. Ankara: Logos Yayıncılık; 2004. p. 503-18, 559-70, 736-7, 740-54.

2. Erdem MK, Özgen S, Coşkun F. Obstetrik Anestezi ve Analjezi. Kişnişci H, Gokşin E, editors. Temel Kadın Hastalıkları ve Doğum Bilgisi. Ankara: Melisa Matbaacilık; 1996. p. 173-86.

3. Santos AC, Fihster M, Pederson H. Obstetric Anesthesia. In: Barash PG, Cullen BF, Stelty RK, editors. Clinical Anesthesia. Philadelphia: JP Lippincott Co; 1998, p. 1267-306.

4. Clark SL. Cesarean Section. In: Hankils GDV, Clark SL, Cunnigham FG, Giltstrap LC, editors. Operative Obstetrics. Connecticut: Appleton and Lange; 1995. p. 301-22.

5. Erdine S. Rejyonal Anestezi. Istanbul: Nobel Tip Kitabevleri; 2005. p. 159-79, 253-70.

6. Morgan GE, Mikhail MS, Murray MJ, Larson CP. Klinik Anesteziyoloji, 4th ed. In: M Tulunay, H Cuhruk, translation editors. Ankara: Öncü Matbaas1; 2004. p. 263-75, 813-15, 874-78, 901-3.

7. Günaydın B. Obstetrik ve Jinekolojik Anestezi. In: Keçik Y, Alkış N,
Yörükoğlu D, Alanoğlu Z, editors. Temel Anestezi. Ankara: Güneş Tip Kitabevleri 2012. p. 549-69.

8. Ateş Y. Spinal, Epidural ve Kaudal Bloklar In: Tulunay M, Cuhruk H, editors, Klinik Anesteziyoloji. Ankara: Güneş Tip Kitabevleri; 2008. p. 289-324.

9. Kocamanoğlu IS, Sarıhasan B, Şener B, Tür A, Şahinoğlu H, Sunter T. Methods and complications of anesthesia in cesarean/section operations: retrospective evaluations of 3552 cases [Article in Turkish]. Turkiye Klinikleri J Med Sci 2005;25:810-6.

10. Öztürk E, But A, Gülhaş N, Begeç Z, Doğan Z, Yapıcı E, Ersoy ÖM. Sezaryende bupivakain ve ropivakainin hemodinami üzerine etkileri. Türk Anest Rean Der Dergisi 2006;34:355-60.

11. Şahin Ş, Owen M. Türkiyéde ve Dünyada Obstetrik Analjezi ve Anestezi. TARCM 2002;30:52-9.

12. Harten JM, Boyne I, Hannah P, Varveris D, Brown A. Effects of a height and weight adjusted dose of local anaesthetic for spinal anaesthesia for elective Caesarean section. Anaesthesia 2005;60:348-53.

13. Darçın S, Borazan H, Otelcioğlu Ş. Comparison the Different Delivery Speeds of Levobupivacaine and Fentanyl in Spinal Anesthesia [Article in Turkish]. Selçuk Üniv Tip Derg 2011;27:27-31.

\section{Spinal Anestezide Farklı Boyutta Enjektörlerin Etkinlik ve Yan Etkilerinin Karşılaştırılması}

Amaç: Doğum öncesi anestezi ve analjezi, doğum sırasındaki ağrıyı azaltmayı amaçlamaktadır. Bu çalışmada aynı lokal anestezi hacmini içeren üç farklı ebatı enjektörün $(2.5 \mathrm{~mL}, 5 \mathrm{~mL}, 10 \mathrm{~mL})$ subaraknoid blok seviyesine, komplikasyonlara ve hasta hemodinamisine olan etkisini araştırdık.

Gereç ve Yöntem: Çalışmamıza subaraknoid anestezi ile sezeryan olan I8-45 yaş grubundaki I20 ASA I-II hastası alındı. Grup l'de $2.5 \mathrm{~mL}$ enjektör, Grup II $5 \mathrm{~mL}$ enjektör ve Grup III $10 \mathrm{~mL}$ enjektör kullanıldı. Hemodinamik parametreler kaydedildi. Motor ve duyusal blok seviyeleri için ameliyat sonrası Bromage skalaları ve Pinprick testleri yapılmış ve blokların geri kazanılma zamanı da kaydedilmiştir. Ameliyat sonrası komplikasyonlar (baş ağrısı, lomber ağrı) ve epidural kan yaması gerektiren olgular kaydedildi.

Bulgular: Grup I ile Grup II arasında T4 dermatoma ulaşma süresi ile ilgili istatistiksel olarak anlamlı fark vardı ( $p=0.002$ ). Grup I için $2.5 \pm 0.8$ dakika, Grup II için $3.2 \pm 0.9$ dakika ve Grup III için $3.2 \pm 1.0$ dakika (Grup I-Grup II $p=0.00$ I, Grup I-Grup III $p=0.002$, Grup II-Grup III $\mathrm{p}=0.843$ ).

Sonuç: Enjektörün çapındaki değişikliğin minimal hemodinamik parametreler üreteceğini düşünüyoruz. Farklı cerrahi prosedürlere sahip diğer hasta gruplarıyla yapılan daha kapsamlı çalışmalar daha kapsamlı sonuçlara neden olacaktır.

Anahtar Sözcükler: Sezeryan; subaraknoid blok; şırınga çapı. 